\title{
Physiological and Morphological Traits of Agronomic Crops Influenced By Climate Change
}

\author{
Imran* \\ Department of Agronomy, University of Agriculture, Pakistan \\ *Corresponding author: Imran, Department of Agronomy, The University of Agriculture, Pakistan
}

Submission: 眥 December 11, 2017; Published: 望眥April 10, 2018

\begin{abstract}
Climate change is a gigantic challenge and threat for food security throughout the globe. Climate change induced by human activities either by natural system manipulation like deforestation, urbanization, industrialization, diversion of behavior for comfortable life passing and by more greenhouse gases (GHG) emission for calmness in life. On the other hand with the calmness in life, changed the Earth's atmosphere and produced aerosols (small particles), and cloudiness in the atmosphere. These aerosol caused global warming and effected agricultural productivity at regional level. There may be a vigorous growth of some crops in raised CO2 conditions, but there is a trade-off because as temperature rises seed production may be drop especially of maize and soybean in tropical regions. Shifting, vanishing and endangering of the marginal crops is increasing rapidly which a big challenge and threats towards food security. Average temperature of the earth, which has been increasing for many years.

In this Context present study was investigated at reginal level of district swat to evaluate the impact of changing climate on crop productivity at various location and crop responses to the changing climate. It was concluded and suggested that production of maize, soybean tomato, cucumber, squashes, peas, French bean, canola and pulses are vulnerable to extreme temperature and drought stress. Therefore climate change is a real fact confronting to agriculture productivity. So proper management with biochar, soil amendments, charcoal and other organic matter will might be promote root density, and will result in more number of roots having more water and nutrients absorption and will ultimately reduce the impact of changing climate.
\end{abstract}

Keywords: Climate change; Maize; Soybean; Yield; GHG; Aerosols

\section{Introduction}

Climate refers to the average weather conditions in a place over many years (usually at least 30 years, to account for the range of natural variations from one year to the next). For example, the climate in Swat Pakistan (Especially upper swat) is cold and snowy in the winter, while Peshawar Pakistan climate is hot and humid. The climate in one area, like the Swat or Peshawar, is called a regional climate. The regional climates have great importance in respect of agricultural productivity, food security, and livelihood. Recent studies have showed that plants and crop responded positively to reginal climate and showed ameliorating effect in term of grain yield, plant height, thousand grain weight, dry matter portioning biological yield, oil yield, and quality of the crops [1-13].

A significant change in the Earth's climate is occurring slowly and gradually and influencing life on the planet earth. Climate can be defined as "expected weather". When changes in the expected weather occur, known as climate changes. They can be defined by the differences between average weather conditions at two separate times. Climate may change in different ways, over different time scales and at different geographical scales. In recent times, scientists have become interested in global warming, due to mankind's impact on the climate system, through the enhancement of the natural greenhouse effect. The Earth is currently getting warmer because people are adding heat-trapping greenhouse gases to the atmosphere. The term "global warming" refers to warmer temperatures, while "climate change" refers to the broader set of changes that go along with warmer temperatures, including changes in weather patterns, the oceans, ice and snow, and ecosystems around the world [1].

The average climate around the world is called global climate. When scientists talk about global climate change, they're talking a pattern of changes happening around the world over many years. One of the most important trends that scientists look for it is the average temperature of the Earth, which has been increasing for many years. The increase in temperature adversely affected all sectors of life but the most vulnerable is agriculture. Water shortage is enhancing day by day due to climate change at arid and semi-arid region which leads to demolish crop production practices. 
How Climate Change is a Threat and Challenge for Food Security

The global warming caused by climate change is likely to affect crops throughout the life cycle due to increased temperature, moisture stress, heat waves, the possible emergence of new major insect-pests and disease [2, 11-14]. It has been reported that mungbean has high nutritive value, and due to this, has advantage over the other pulses known as king of the pulse crop. The seed contains $24.20 \%$ protein content, $1.30 \%$ fat, and $60.4 \%$ carbohydrates; calcium (Ca) is 118 and phosphorus (P) is $340 \mathrm{mg}$ per $100 \mathrm{~g}$ of seed but due to increase in temperature the quality and production potential of the crop going to decline. The quality of crops were examined by and $[1,2,15]$.

They have been reported that pulses are known as poor man's meat and cheap source of vegetable protein containing $20-25 \%$ protein. Its production is very low in many regions due to miss management of the inputs. Therefore, if farmers implement more number of tillage practices as compared to conventional, so the nutrients demand will be fulfilled by the leached and adsorbed nutrients, away from root zone by pulverizing the soil, whereas the productivity of the soil will also increase with soft soil, promote root density, and will result in more number of nodules having more nitrogen fixation and will ultimately reduce the impact of changing climate [2].

\section{Response of germination to changed climate}

Crop seeds germinate in a particular range of temperature. Increase in soil temperature by global warming will adversely affect germination and therefore crop stand will be affected respectively. For example, groundnut which is a major crop of KP has an optimum temperature of $25-30{ }^{\circ} \mathrm{C}$ for germination. Increase in temperature beyond this range during the sowing time will adversely affect crop germination. [2,11-14]. They have reported that Canola cultivars positively responded in optimum temperature range to sulphur fertilization in term of seed yield and oil quality. [2,11-14] concluded that Oscar cultivar increased seed yield 53\% as compared to control plots when there were no fluctuation in temperature.

Sulphur at the rate of $45 \mathrm{~kg} \mathrm{ha}^{-1}$ increased seed yield, biological yield, and quality of rapeseed. Imran I [1,2] revealed that in optimum temperature number of days to flowering (76), number of pods plant ${ }^{-1} 372$ ), number of seeds pod $^{-1}$ (24), plant height $(173 \mathrm{~cm})$, biological yield $\left(15547 \mathrm{~kg} \mathrm{ha}^{-1}\right)$, seed yield $\left(2209 \mathrm{~kg} \mathrm{ha}^{-1}\right)$, index (19\%), glucosinolate $\left(\mu \mathrm{mol} \mathrm{g}^{-1}\right)$ content $\left(31.03 \mu \mathrm{mol} \mathrm{g}^{-1}\right)$ and oil content (45.81\%) was significantly with sulphur treated@45kg ha $^{-1}$ applied plots as compared to delayed flowering (78 days), shortest $(151 \mathrm{~cm})$, pods formation (298 pods), seed $\operatorname{pod}^{-1}$ (21), biological yield $\left(11090 \mathrm{~kg} \mathrm{ha}^{-1}\right)$, seed yield $\left(1436 \mathrm{~kg} \mathrm{ha}^{-1}\right)$, and oil content (42.62\%) in control plots. Among cultivars "Oscar" ranked first in growth stages and attain more plant height $(164 \mathrm{~cm})$, and examined substantial number of pods plant ${ }^{-1}$ (359), seeds pod ${ }^{-1}$ (24), seed yield (2005 $\left.\mathrm{kg} \mathrm{ha}^{-1}\right)$, biological yield (14298kg ha-1), harvest index $17 \%$, and oil content $46.29 \%$ ) as compared to other sowed cultivars. On the basis of the result it is recommended that cultivar "Oscar" treated with sulphur@45 $\mathrm{kg} \mathrm{ha}^{-1}$ should be applied for higher yield and quality of rapeseed under agro-climatic condition of swat valley.

\section{Response of changed climate towards growth and development}

Temperature higher than the optimum range adversely affects growth and development of plants due to harmful effects on plant metabolic activities. The rate of photosynthesis may get more sluggish as the temperature increases due to closure of stomata. Besides, higher temperature enhances the rate of evapotranspiration causing moisture stress in plants under rain-fed situations. Also at higher temperature the dry matter accumulation becomes less. Shoot cutting duration after date of sowing (ADS), (no cutting, 30 days ADS, 40 days ADS, 50 days ADS and 60 days ADS) were used in the experiment with the test cultivar Dunkled.

From the results it is observed that rapeseed cultivar positively responded for days to flowering, days to maturity, number of branches plant ${ }^{-1}$, H.I \%, number of seeds $\operatorname{pod}^{-1}$, seed weight (g), biological yield $\left(\mathrm{kg} \mathrm{ha}^{-1}\right)$, seed yield $\left(\mathrm{kg} \mathrm{ha}^{-1}\right)$ and oil yield $\left(\mathrm{kg} \mathrm{ha}^{-1}\right)$ to biochar levels maximum seeds pod $^{-1}$ (23 seeds), thousand seed weight $(3.59 \mathrm{~g})$, biological yield $\left(10310 \mathrm{~kg} \mathrm{ha}^{-1}\right)$, seed yield $1169 \mathrm{~kg}$ $\left.\mathrm{ha}^{-1}\right)$ and oil yield $\left(600 \mathrm{~kg} \mathrm{ha}^{-1}\right)$ was observed in plot treated with 10 ton biochar ha-1. Whereas minimum seeds pod $^{-1}$ (15 seeds), thousand seed weight (2.41g), biological yield (6725kg ha-1), seed yield ( $\left.923 \mathrm{~kg} \mathrm{ha}^{-1}\right)$ and oil yield ( $\left.401 \mathrm{~kg} \mathrm{ha}^{-1}\right)$ was recorded in control plot. Similarly highest seeds $\operatorname{pod}^{-1}(22)$, thousand seed weight (3.3g), seed yield (1099 $\mathrm{kg} \mathrm{ha}^{-1}$ ) was noted in no shoot cutting plot followed by shoot cutting after 60 days of sowing ADS plots while promising biological yield (9025 $\mathrm{kg} \mathrm{ha}^{-1}$ ), and oil yield (568kg ha${ }^{1}$ ) was recorded in shoot cutting after 50 days ADS and after 60 days ADS of sowing. On the basis of the result it was concluded that shoot cutting with 10 ton biochar ha ${ }^{-1}$ produced highest seed and oil yield with green chop and recommended for higher seed, oil and biological yield in the agro- climatic condition of swat valley.

\section{Response towards plant reproduction}

Higher temperature has harmful effects on flowering, pollination, fruit setting, and maturation. Higher temperatures may increase flower and fruit dropping in some crops, and cause stigma and pollens to dry $[1,2,5,7-10,11,13,14,16,17]$. The anthelmintic activity was very significant against the tested earthworms. Leaf extracts of Iphionagrantioides and P. Arguta at dose of $100 / \mathrm{ml}$ caused death of the worms in $3.33 \pm 0.57$ and $2.16 \pm 0.28$ minutes, respectively, which is similar to the effect produced by commercial anthelmintic drug, Piperazine Citrate.

Indicated that both the plants have significant antilice potential by showing $100 \%$ lice mortality in case of Iphionagrantioides leaf followed by its flower (96.67\%) and of Pluchea arguta by causing $93.33 \%$ lice mortality. Iphionagrantioides showed 
excellent insecticidal (90\%) activity against Callosobruchusanalis, Rhyzoperthadominica, Sitophilusoryzae and Triboliumcasteneum. Plucheaarguta leaf exhibited significant activity against all the tested insect species. The results also depicted excellent effect of both the plants by inhibiting growth of Lemna minor. Plant extracts of the plants displayed significant cytotoxicity against brine shrimps. The LD 50 values for all the crude extracts of Iphiona grantioides and Pluchea arguta sub sp. glabra were found to be $34.65,242.83,6.21,29.92 \mathrm{ug} / \mathrm{ml}$ and $0.02,0.03$ and $84.66 \mathrm{ug} / \mathrm{ml}$ respectively. The present studies showed that ethanolic extracts of Iphionagrantioides and Pluchea argura sub sp. Glabra revealed significant potential regarding anthelmintic, antilice, insecticidal cytotoxic and phytotoxic activity and these plants could be exploited for herbal drugs exploration for the health care of mankind.

\section{Response towards crop duration}

The increase in temperature will speed the maturity, so cutting the total duration of the crop. It will result in lower dry matter accumulation and lower yield. The effect of nitrogen on days to flowering was significant. With increase in nitrogen level significant delayed were noted in days to flowering. Plots treated with different decapitation stresses delay days to flowering as compared to plots. The interaction between nitrogen levels and decapitation stress on days to flowering were also found significant with $100 \mathrm{~kg}$ nitrogen level and $5 \mathrm{~cm}$ decapitation stress shows maximum (111) days to flowering. This might be due to maximum nitrogen enhances vegetative growth and delayed reproductive phase. This statement are supported by Ahmadi \& Bahrani who's reported the effect of nitrogen levels and concluded that highest $\mathrm{N}$ level enhanced plant height, number of branches plant ${ }^{-1}$ and maximum days to flowering.

\section{Response towards crop yield and productivity or total biomass}

Lower plant stand due to poor germination, low dry matter accumulation, adverse effects on flowering and fruiting, reduced crop duration caused by an increase in temperature will ultimately reduce the crop yield. Still, in case of $\mathrm{C}_{3}$ plants the enhanced level of $\mathrm{CO}_{2}$ may result in higher rate of photosynthesis and increase yield. But such effects of $\mathrm{CO}_{2}$ fertilization may get negated due to higher temperature and moisture stress caused by climate change $[1,2,5,7,8,10,11,14,16,18]$ examined that regional climate is very important for an ideal crop growth and production. (Table 1 \& 2) shows five different crop average yield grown and different elevation and topography with different rainfall pattern and temperature [19-52]. Differences in the average temperature of a locality have significant effect on crop growth, yield and productivity.

\section{References}

1. Imran I, Khattak I, Hussain, Rehman A, Anwar S, et al. (2015) Growth and Yield of Maize Hybrids as effected by different Sowing Dates in Swat Pakistan. J Pure \& Applied biology 4(4).

2. Imran I, Hussain I, Khattak, Rehman A, Ahmad F, et al. (2015) Roots nodulation, yield and yield contributing parameters of mungbean cultivars as influenced by different phosphorous level in swat-Pakistan. Pure Appl Biol 4(4): 557-567.
3. Imran, Asad Ali Khan, Fayaz Ahmad (2015) Phenology of Various Rice Genotypes as Affected by Different Transplanting Dates under Cold Climatic Region of Khyber Pakhtunkhwa-Pakistan. Journal of Environment and Earth Science 5(3).

4. Imran, Asad Ali Khan (2015) Phenological Charateristics of Brassica Napus L. as Influenced by Biochar Application and Shoot Cutting Duration (Days). Civi and Environ Res 7(3).

5. Naveed, Muhammad Ibrar, Inayat Khattak, Imtiaz Khan, Imran, et al (2016) Anthelmintic, Antilice, Insecticidal, Cytotoxic And Phytotoxic Potential Of Ethanolic Extracts Of Two Wild Medicinal Plants Iphiona Grantioides And Plucheaarguta. J Woulfenia 23(11): 13-25.

6. Imran, Asad Ali Khan, Fayaz Ahmad, Irfanullah (2015) Influence of Hydrated Calcium Sulphate $\left(\mathrm{CaSO}_{4}, 2 \mathrm{H}_{2} \mathrm{O}\right)$ and Nitrogen Levels on Water Infiltration Rate and Maize Varieties Productivity in Rainfed Area of Swat, Pakistan. Chemistry and Material Research 7(3).

7. Baqa, Amir Zaman Khan, Inamullah, Imran, Asad Ali Khan, et al. (2015) Influence Of Farm Yard Manure And Phosphorus Application On Yield And Yield Components Of Wheat. J Pure \& Applied biology 4(4).

8. Iqbal, Jan MT, Imran, Zar M, Khan AA, et al. (2015) Growth and phenology of maize as affected by integrated management of compost and fertilizers Nitrogen. J Pure \& Applied biology 4(4).

9. Islam M, Shazma Anwar, Saqib Bashir, Wajid Ali Khattak (2015) Growth and Yield Components of Wheat Varieties As Affected By Dual Purpose Practices. J Pure \& Applied biology 4(4): 491-496.

10. Iqbal, Mohammad Tariq Jan, Zar Muhammad, Asad Ali Khan, Shazma Anwar, et al. (2016) Phenological traits of Maize influenced by integrated management of compost and fertilizer Nitrogen. J Pure \& Applied biology 5(1): 58-63.

11. Samreen, Muhammad Ibrar, Lalbadshah, Shahida Naveed, Imran, et al. (2016) Ethnobotanical study of subtropical hills of Darazinda, Takht-eSuleman range F.R D.I. Khan, Pakistan. Pure and Applied Biology 5(1): 149-164.

12. Anwar, Israeel, Babar Iqbal, Asad Ali Khan, Imran, et al. (2016) Nitrogen and phosphorus fertilization of improved varieties for enhancing phonological traits of wheat. Pure and Applied Biology 5(3): 511-519.

13. Khan AZ, Imran, Asim Muhammad, Aiman Khalil, Hasina Gul, et al. (2016) Impact of fertilizer priming on seed germination behavior and vigor of maize. Pure Appl Bio 5(4): 744-751.

14. Barnola JM, Raynaud D, Korotkevich YS, Lorius C (1987) Vostok ice core provides 160,000-year record of atmospheric $\mathrm{CO}_{2}$. Nature 329: 408-414.

15. Imran, Khan, Russ AA (2017) Agricult Sci 43.

16. Iqbal A, Amanullah, Ali A, Iqbal M, Ikramullah, et al. (2017) Integrated use of phosphorus and organic matter improve fodder yield of moth bean (Vignaaconitifolia (Jacq.) under irrigated and dryland conditions of Pakistan. Journal of Agri Search 4(1): 10-15.

17. Imran, Khan AA, Inamullah, Luqman (2015) Weeding stages and their effect on yield and yield components of rice in upper Swat, Pakistan. Pakistan Journal of Weed Science Research 21(4): 555-563.

18. Imran (2017) Climate Change Is a Real Fact confronting to Agricultural Productivity. Int J Environ Sci Nat Res 3(3).

19. Lal R (2001) Potential of Desertification Control to Sequester Carbon and Mitigate the Greenhouse Effect. Climatic Change 51(1): 35-72.

20. Lockwood J (2012) Atmospheric Moisture. In: Holden J (Eds.), An introduction to Physical Geography and the Environment Pearson. England 875.

21. Marengo J (2006) On the hydrological cycle of the Amazon Basin: a historical review and current state of the art Revista Brasileira de Meteorologia 21(3): 1-19. 
22. Shaw EM, Beven KJ, Chappell N, Lamb R (2010) Hydrology in Practice. CRC Press, ( $4^{\text {th }}$ edn), London, UK, England.

23. Trenberth KE, Smith L, Qian T, Dai A, Fasullo J (2007) Estimates of the Global Water Budget and its Annual Cycle Using Observational and Model Data. J Hydrometeor 8: 758-769.

24. Ali Whitmer, Marine Science Institute, University of California, Santa Barbara, Bruce Caron, The New Media Studio, et al. (2005) Visualising carbon pathways.

25. Imran (2015) Effect of Germination on Proximate Composition of Two Maize Cultivars. Journal of Biology, Agriculture and Healthcare 5(3): 123-128.

26. Abbot CG (1910) The solar constant of radiation. Smithsonian Institution Annual Report 319.

27. Ackerman T, Stokes G (2003) The Atmospheric Radiation Measurement Program. Physics Today 56: 38-44.

28. Adkins JF (1998) Deep-sea coral evidence for rapid change in ventilation of the deep North Atlantic 15,400 years ago. Science 280: 725-728.

29. Barnett TP (1999) Detection and attribution of recent climate change: $A$ status report. Bull Am Meteorol Soc 80: 2631-2660.

30. Imran, Asad Ali Khan, Fayaz Ahmad, Irfanullah (2015) Nitrogen Levels, Tillage Practices and Irrigation Timing Influenced Yeild, Yeild Components and Oil Contents of Canola. Civil and Environmental Research 7(3).

31. Imran, Fazal Maula, Muhammad Uzair, Hayat Zada (2015) Farmers Income Enhancement through Off-Season Vegetables Production under Natural Environment in Swat-Pakistan. J Environ and E Science.

32. Battle M (1996) Atmospheric gas concentrations over the past century measured in air from firm at South Pole. Nature 383: 231-235.

33. Imran, Asad Ali Khan (2015) Grain Yield and Phenology of Maize Cultivars Influenced by Various Phosphorus Sources. Food Science and Quality Management 37.

34. Imran, Asad Ali Khan (2015) Biochar Application and Shoot Cutting Duration (days) Influenced Growth, Yield and Yield Contributing Parameters of Brassica Napus L. Journal of Biology, Agriculture and Healthcare 5(5): 1-6.

35. Bender M, Ellis T, Tans P, Francey R, Lowe D (1996) Variability in the $\mathrm{O}_{2} / \mathrm{N}_{2}$ ratio of southern hemisphere air, 1991-1994: Implications for the carbon cycle. Global Biogeochemical Cycles 1: 9-21.

36. Berger A, MF Loutre, Gallée H (1998) Sensitivity of the LLN climate model to the astronomical and $\mathrm{CO}_{2}$ forcings over the last $200 \mathrm{kyr}$ Clim Dyn 14: 615-629.

37. Imran, AA Khan, Ullah I, Zada H, Ahmad F, et al. (2015) Yield and yield attributes of rapeseed cultivars as influence by sulfur level under swat valley conditions. J Pure \& Applied biology 4(3).

38. Iqbal A, Amanullah, Ali A, Iqbal M, Ikramullah, et al. (2017) Integrated use of phosphorus and organic matter improve fodder yield of moth bean (Vigna aconitifolia (Jacq.) under irrigated and dryland conditions of Pakistan. Journal of Agri Search 4(1): 10-15.
39. Imran, Shaheeda Naveed, Asad Ali Khan, Inayat Khattak (2015) Impact Of Phosphorus Levels And Seed Rates On Growth And Yield Of Late Sown Maize On High Elevation In Swat, Pakistan. Pakistan J Agric Res 28(4): 406-413.

40. Imran, Khan AA, Khan IU, Naveed S (2016) Weeds density and late sown maize productivity influenced by compost application and seed rates under temperate environment. Pakistan Journal of Weed Science Research 22(1): 169-181.

41. Iqbal, Bashir Ahmad, Inam Ullah, Imran, Asad Ali Khan, et al. (2016) Effect of phosphorus, sulphur and different irrigation levels on phonological traits of Triticale. Pure and Applied Biology 5(2): 303-310.

42. Imran, Zada H, Naveed S, Khattak I, Ahmad S (2016) Variable Rates Of Phosphorous Application Influenced Phenological Traits Of Green Gram (Vignaradiata L.). Open Access Journal of Agricultural Research 1(3): $1-5$

43. Imran, Asad Ali Khan, Inamullah Inam, Fayaz Ahmad (2016) Yield and yield attributes of Mungbean (Vignaradiata L.) cultivars as affected by phosphorous levels under different tillage systems. Cogent Food \& Agriculture 2(1).

44. Khan AA, Khan MN, Uallah I, Shah S, Arshad IR, et al. (2015) Effect of potash application on growth, yield and yield components of spring maize hybrids. Pure and Applied Biology 4(2): 195-203.

45. Iqbal, Muhammad Tariq Jan, Inamullah, Imran, Asad Ali Khan, et al. (2015) Integrated Management of Compost Type and Fertilizer- $\mathrm{N}$ in Maize. J Pure \& Applied biology 4(4).

46. Imran, Khattak I, Hussain I, Rehman A, Anwar S, et al. (2015) Growth and Yield of Maize Hybrids as effected by different Sowing Dates in Swat Pakistan. J Pure \& Applied biology 4(4).

47. Imran, Hussain I, Khattak I, Rehman A, Ahmad F, et al. (2015) Roots nodulation, yield and yield contributing parameters of mungbean cultivars as influenced by different phosphorous level in swat-Pakistan. J Pure \& Applied biology 4(4): 557-567.

48. Imran, Asad Ali Khan, Irfanullah, Fayaz Ahmad (2014) Production potential of rapeseed (Brassica napus L.) as influenced by different nitrogen levels and decapitation stress under the rainfed agro-climatic condition of swat Pakistan. J Glob Innov Agric Soc Sci 2(3): 112-115.

49. Asad AK, Imran, Fawad Ali Shah, Inamullah, Laiq Zada, et al. (2015) Phenological Traits of Rice as Influenced by Seedling Age and Number of Seedling per Hill under Temperate Region. J Bio Agric H care.

50. Imran, Asad Ali Khan, Kashif Akhtar, Sajjad Zaheer, Shah Faisal, et al. (2015) Rice Seedling Characteristics of Various Genotypes Influenced by Different Sowing Dates in Swat-Pakistan. J Environ and E Science.

51. Imran (2015) Influence of Nitrogen Levels and Decapitation Stress on Biological Potential of Rapeseed (Brassica Napus L) under Water Difficit Condition of Swat-Pakistan. J N Sci Res.

52. Imran, Asad Ali Khan, Hayat Zada, Fayaz Ahmad, Irfanullah (2015) Graine Yield and Yield Components of Wheat Cultivar "Siran 2010" As Affected by Phosphorous Levels under Rain fed Condition. Journal of Natural Sciences Research 5(5): 139-143.
Creative Commons Attribution 4.0 International License

For possible submissions Click Here

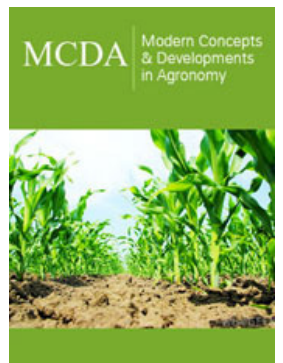

Modern Concepts \& Developments in Agronomy

\section{Benefits of Publishing with us}

- High-level peer review and editorial services

- Freely accessible online immediately upon publication

- Authors retain the copyright to their work

- Licensing it under a Creative Commons license

- Visibility through different online platforms 